\title{
MJMR THE RELATIONSHIP OF EARLY BREASTFEEDING INITIATION WITH POSTPARTUM MATERNAL PROLACTIN LEVELS
}

\author{
Arfianingsih Dwi Putri \\ Lecturer of Midwifery, Midwifery of Alifah Academy Padang-Indonesia \\ Corresponding Author's Email: Arfianingsih_dwiputri@yahoo.com
}

\begin{abstract}
Breastfeeding (ASI) is the best way to meet the nutritional needs for growth and development of infants. The scope of exclusive breastfeeding in the city of Padang in West Sumatra province in 2014 reached $72.2 \%$. This level is still far below the national target of $80 \%$ in 2015. One of the ways that support successful breastfeeding is Early Initiation of Breastfeeding (IMD). The first hour after the baby was born is a golden opportunity to determine the success of a mother to breastfeed her baby because the baby had been trained optimally instinctively find their own mother's nipple. The purpose of this study was to determine the influence of IMD against postpartum maternal prolactin levels. The decrease of breast milk production and milk ejection after delivery could be caused by a lack of stimulation of prolactin and oxytocin hormone which has an important role in production and ejection of breast milk. The purpose of this study was to the correlation of IMD on postpartum maternal prolactin levels.
\end{abstract}

This study was an analytical study with the cross-sectional study. It was conducted at a midwifery clinic in Padang and at the Biomedical laboratory of Andalas University in August 2014 to November 2016 with 50 postpartum subjects (each group was 25 subjects).

The result of this study showed that the mean prolactin level in the successful early breastfeeding group was 314,88 $\pm 40,38 \mathrm{ng} / \mathrm{ml}$, while prolactin level in unsuccessful early breastfeeding group was $144,481 \pm 28,101 \mathrm{ng} / \mathrm{ml}(p=$ $0.000)$.

It is concluded that there is a significant correlation between Early Breastfeeding Initiation (IMD) with prolaktin postpartum.

Keywords: Early Breastfeeding Imitation, Prolactin

\section{INTRODUCTION}

The development of a healthy, intelligent, and pious generation is the responsibility of all components of society, both from top-level officials to the commoners, even the main basis lies with women, namely Mother. Mother has a role and responsibility to give birth to an intelligent and pious generation so that it can give color to our beloved country and be able to make the nation ready and able to lead (UNICEF, 2007).

The United Nations Childrens Found (UNICEF) also explained as many as 30,000 infant deaths in Indonesia and 10 million deaths of children under five in the world each year, could be prevented through exclusive breastfeeding for six months from the date of birth, without having to provide food and additional drinks to babies (Aprilia, 2009).

Breastfeeding has a positive impact both for the mother and for the baby. For breastfeeding babies have an important role in the growth, health, and survival of babies because breast milk is rich in nutrients and antibodies. For you, breastfeeding can prevent pregnancy, reduce the risk of breast cancer and ovarian cancer, is more economical and practical (Riordan,2005).

Besides that, breastfeeding is the best way to meet nutritional needs for baby's growth and development, especially for cognitive, sensory development and provide protection against infections and chronic diseases and bring a positive impact on maternal health with the duration of exclusive breastfeeding is 6 months (et al., 2005).

The coverage of exclusive breastfeeding in the city of Padang in West Sumatra Province in 2014, namely in the City of Padang in 2014 reached $72.2 \%$. This achievement is still far below the national target of $80 \%$ in 2015. Padang City has 22 Public Health Service with the highest coverage of exclusive breastfeeding is Alai health center at $90.6 \%$ and the second highest coverage of exclusive breastfeeding is $85.6 \%$ Belimbing Health Center. The lowest exclusive breastfeeding coverage is in the Cold Water Health Center 52.6\% (Dinas Kesehatan Kota Padang, 2013). 
Not breastfeeding in the first days after giving birth is one of the reasons for not creating exclusive breastfeeding. Early breastfeeding until a baby is 6 months old can be influenced by several factors. Factors that become constraints are the process of growing breastfeeding-making networks, the commencement of milk production after the baby is born, the continuity or continuity of breastmilk production, and expenditure reflexes. Decreased production and release of breast milk after childbirth can be caused by a lack of stimulation of the prolactin and oxytocin hormones which greatly contribute to the smooth production and expenditure of breast milk (Kementerian Kesehatan, 2015).

One way to support the success of breastfeeding immediately after birth or commonly called Early Breastfeeding Initiation (EBI). EBI can reduce neonatal mortality by $22 \%$. If the breastfeeding process starts after the first hour of birth but not past 24 hours, it can only reduce neonatal mortality by $16 \%$. In addition to reducing neonatal mortality, EBI has also been shown to play a role in the success of the subsequent breastfeeding process (Roesli, 2008).

EBI in Indonesia, shows an alarming fact that when viewed from the EBI rate $(<1$ hour after the baby was born) only $34.5 \%$ of babies were carried out, most of the breastfeeding process was carried out in the range of 1-6 hours after birth and apparently there were 11, $1 \%$ of the process of starting breastfeeding is done after 48 hours. As many as $43.6 \%$ of babies have been given prelacteal food (food or drink given to newborns before breast milk comes out), the percentage of babies who breastfeed exclusively up to the age of 6 months is only 30.2\% (Riskesdas, 2013).

The first hour after the baby is born is a golden opportunity that will determine the success of the mother to breastfeed her baby optimally because the baby has been trained instinctively to find her own mother's nipple. If the baby can suckle in 20-30 minutes will help the baby get his first ASI, build a bond of love for mother and baby, so that it can increase milk production which eventually the next breastfeeding process will be better, because it is influenced by prolactin and oxytocin hormones (Roesli,2008).

Prolactin and oxytocin are hormones that affect milk production. At one hour of labor the hormone prolactin will decrease due to the release of the placenta and to maintain prolactin oxytocin is needed which can be stimulated by baby suction so that it can stimulate the release of breast milk. Breastfeeding less than half an hour after childbirth is able to prevent the decrease in the hormone prolactin in the mother's blood circulation so that colostrum on the first day will go out faster. However, if the baby does not suck on the nipples one hour after delivery, the hormone prolactin will decrease and it is difficult to stimulate prolactin so that milk production is less smooth and new ASI will come out on the third day or so (Noel, Suh \& Franz, 2009).

Grewen (2013) states that the hormone prolactin levels will decrease after several hours of labor and before the baby is breastfed, the prolactin level will increase after breastfeeding, especially after the baby is born. Eight out of ten women who give birth will experience an increase in prolactin hormone concentrations between 1 and 4 minutes after starting EBI. There is an increase in the concentration of the prolactin hormone that stimulates milk production after EBI (Riordan, 2005).

According to Roesli (2008), there is a significant relationship between EBI and the speed of breastfeeding in post partum mothers. EBI which is done correctly most of the speed of Breastmilk discharge is normal, namely as much as $87.5 \%$, and EBI that is not right, the speed of discharge of breastmilk is slow, which is $12.5 \%$.

\section{METHODOLOGY}

This research was conducted at the Padang City Independent Practice Midwife, namely Midwife Widra, A.Md. Keb, Midwife Hj. Nurhaida, AMd. Keb and Midwife Sensmice, ZA, S.SiT. Research samples were 50 people who met the inclusion criteria and agreed to participate in the study. Of the 50 respondents, there were 25 respondents with babies who successfully carried out EBI and 25 respondents with babies did not succeed in EBI. The data obtained were grouped and tabulated according to the characteristics of each variable. The relationship between EBI and prolactin levels. Postpartum mothers were tested with Mann-Whitney. Before being tested with Mann-Whitney, the data normality test was used using the Shapiro-Wilk test because it had a sample of 50 people.

Based on the normality test with Shapiro-Wilk obtained prolactin levels with a value of $p=0.001$. This indicates that the data is not normally distributed. Furthermore, several data transformation steps were taken which were then carried out by non-parametric (Mann-Whitney) test to correlate EBI with postpartum maternal prolactin levels. 


\section{RESULTS}

Table 1: Characteristics of Respondents Research Based on the Age

\begin{tabular}{|c|l|l|l|}
\hline \multicolumn{3}{|c|}{ EBI Group } & \\
\hline Characteristic & Succesful & Unsuccesful & $\boldsymbol{P}$ \\
\cline { 2 - 3 } & $\boldsymbol{n}=\mathbf{2 5}$ & $\boldsymbol{n}=\mathbf{2 5}$ & \multirow{2}{*}{0.295} \\
\cline { 2 - 3 } & Rate \pm SD & Rerata \pm SD & \\
\hline Age & $27.52 \pm 3.698$ & $29.00 \pm 5.923$ & \\
& & & \\
\hline
\end{tabular}

Description: unpaired T test

Based on Table 1 it can be seen that the average age of respondents in the successful group IMD and unsuccessful EBI were $27.52+3.698$ years and $29.00+$ 5.923 years, respectively. Based on the results of statistical tests it is known that there is no age relationship to the success of $\mathrm{EBI}(p>0.05)$.

Table 2: Characteristics of Research Respondents Based on Parity, Education and Extension

\begin{tabular}{|l|l|l|l|l|l|l|}
\hline \multicolumn{7}{|c|}{ EBI Group } \\
\hline \multirow{2}{*}{ Characteristic } & \multicolumn{2}{|c|}{ Succesful } & \multicolumn{2}{c|}{ Unsuccesful } & $p$ \\
\cline { 2 - 7 } & \multicolumn{2}{|c|}{$n=25$} & \multicolumn{2}{c|}{$n=25$} & \\
\hline 1. & Parity & & & & & \\
\hline & Primipara & 14 & $60.9 \%$ & 9 & $39.1 \%$ & \\
\hline & Multipara & 11 & $40.7 \%$ & 16 & $59.3 \%$ & 0.156 \\
\hline 2. & Education & & & & & \\
\hline & High & 16 & $66.7 \%$ & 8 & $33.3 \%$ & \\
\hline & Low & 9 & $34.6 \%$ & 17 & $65.4 \%$ & 0.024 \\
\hline 3. & Extension & & & & & \\
\hline & Yes & 24 & $85.7 \%$ & 4 & $14.3 \%$ & \\
\hline & No & 1 & $4.5 \%$ & 21 & $95.5 \%$ & 0.000 \\
\hline
\end{tabular}

Based on Table 2, it can be seen that 9 primiparas (39.1\%) were unsuccessful in carrying out EBI and 16 multiparas $(59.3 \%)$ also did not succeed in implementing EBI. The results of the statistical test showed no relationship between parity and the success of $\mathrm{EBI}(p>0.05)$.

Table 3: Relationship to EBI with Prolactin Levels Postpartum

\begin{tabular}{|r|c|l|l|l|}
\hline EBI & $\boldsymbol{N}$ & $\begin{array}{l}\text { Prolactin levels } \\
\text { Mean } \pm \text { SD }\end{array}$ & $\begin{array}{l}\text { Median } \\
\text { (min-max) }\end{array}$ & p value \\
\hline Succesful & 25 & $\begin{array}{l}314.88 \pm 40.381 \\
\mathrm{ng} / \mathrm{ml}\end{array}$ & $306(240-377)$ & \multirow{2}{*}{0.000} \\
\cline { 2 - 2 } & 25 & $\begin{array}{l}144.48 \pm 28.101 \\
\mathrm{ng} / \mathrm{ml}\end{array}$ & $147(105-187)$ & \\
\hline
\end{tabular}

Based on table 3, the mothers who succeeded in EBI had higher prolactin levels of $314.88 \pm 40.381 \mathrm{ng} / \mathrm{ml}$ compared to those who did not succeed EBI at $144.48 \pm$ $28.101 \mathrm{ng} / \mathrm{ml}$. The statistical test results obtained $p$ value $<0.05(p=0,000)$ which means there is a relationship between IMD and postpartum maternal prolactin levels.

\section{DISCUSSION}

The relationship between Early Breastfeeding Initiation (EBI) and Postpartum Maternal Prolactin Levels

The results of the EBI relationship analysis with prolactin levels in postpartum mothers showed that the average prolactin level was higher in the group that succeeded in EBI which was $314.88 \pm 40.381 \mathrm{ng} / \mathrm{ml}$, while prolactin levels in postpartum mothers were unsuccessful EBI $144.48 \pm 28.101 \mathrm{ng} / \mathrm{ml}$. The statistical test results obtained $p$ value $<0.05$, which means there is a relationship between Early Breastfeeding Initiation (EBI) and postpartum maternal prolactin levels.

Breast feeding provides all the nutrients needed by the baby and the immunological components needed by a mature baby. Other benefits include breastfeeding which can reduce the risk of infection, prevent allergies, improve baby cognitive, prevent obesity and hypertension (Maryunani, 2012). The first hour after the baby is born is a golden opportunity that will determine the success of the mother to breastfeed her baby optimally because an already trained baby instinctively finds his mother's nipples themselves. If the baby can suckle in 20-30 minutes, it will help the baby get his first milk, build a bond of love between mother and baby, so that it can increase milk production, which in turn will make the next breastfeeding process better (Roesli, 2008).

Physiologically, there are several types of hormones that play a role in the mechanism of breastmilk formation, including the hormone progesterone acts to stimulate the formation of lobes and alveoli, the hormone estrogen triggers ductal widening in the mammary gland and stimulates the anterior pituitary in removing prolactin, and human chorionic somatomammotropin (hCS) is a placental hormone that plays a role in the synthesis of enzymes that are useful for the production of breast milk. Breastfeeding is the optimal method in feeding infants (Sheerwood, 2007).

The production of breast milk itself is influenced by two hormones namely prolactin and oxytocin, at one 
hour the prolactin hormone will decrease due to the release of the placenta and to maintain prolactin oxytocin is needed which can be stimulated by baby suction so that it can stimulate the release of milk. By giving ASI less than half an hour after delivery the prolactin hormone level does not have time to go down in the blood circulation of the mother so that colostrum for the first day will come out faster. However, if the baby does not suck the nipple at half an hour after delivery the prolactin hormone will decrease and it is difficult to stimulate prolactin so that the milk production is not smooth and the new milk will come out on the third day or more, and this will force the midwife to provide breastmilk substitutes because the baby not getting enough milk, and will cause fussy babies (Hollbrook, 2012).

Prolactin is needed for the production of breast milk by alveoli cells. The level of prolactin in the blood increases sharply during pregnancy, and stimulates the growth and development of mammary tissue, in preparation for the production of breast milk. However, breast milk not secreted, because of progesterone and estrogen, blocks the action of prolactin. After giving birth, progesterone and estrogen levels decrease rapidly, the release of prolactin is no longer inhibited, and ASI secretion begins. When the baby suckles, the level of prolactin in the blood increases and stimulates the production of breast milk by the alveoli. The highest prolactin level is around 30 minutes after the start of breastfeeding, so the most important effect is to make breast milk for the next breastfeeding period. During the first few weeks, the more often the baby suckles and stimulates the nipple, the more prolactin is produced, and more milk is produced. This effect is very important during lactation. Although prolactin is still needed for breast milk production, after a few weeks there is no close relationship between the amount of prolactin and the amount of milk produced. However, if the mother stops breastfeeding, the secretion of milk will stop too, then the milk will dry out (WHO, 2009).

The prolactin hormone is produced by the anterior pituitary gland. Prolactin will be in the blood circulation for 30 minutes after the baby suckles, so that prolactin can stimulate the breast to produce breast milk for subsequent consumption, while for consumption at this time, the baby drinks existing milk which is stored in the lactiferous sinus (Roesli, 2008).

Riordan (2005), states that the hormone prolactin level will decrease after several hours of labor and before the baby is breastfeeding, but prolactin levels will increase after breastfeeding activities especially immediately after the baby is born. Eight out of ten women who give birth will experience an increase in the hormone prolactin concentration between 1 and 4 minutes after starting IMD. There is an increase in the hormone prolactin concentration and breast milk production after IMD (Riordan, 2005).The prolactin of lactating women produced in response to sucking is important for maintaining lactation. The prolactin expenditure pattern differs every stage of lactation. The frequency of breastfeeding is associated with an increase in prolactin concentration during the 24-hour lactation period (Greenstein, 2007).

Breastfeeding is strongly associated with prolactin concentration, its level is related to the duration of breastfeeding in the postpartum period. The effect of breastfeeding and breast stimulation on plasma prolactin measured by homologous radioimmunoassay shows that at prolactin levels breastfeeding women have increased and during the first 6 weeks postpartum; means that prolactin increases rapidly during the breastfeeding period and reaches a peak of 8.5 times the base value (Riordan, 2005).

\section{CONCLUSION}

To conclude it can be said that there is a relationship between early breastfeeding initiation (EBI) with postpartum maternal prolactin levels.

\section{REFERENCES}

Aprilia, Y. (2009). Analysis of Socialization of Early Breastfeeding and Exclusive Breastfeeding Initiation Programs to Midwives in Klaten Regency. Retrieved from: http://eprints.undip. ac.id/23900/1 /Yesie_Aprillia.pdf

Dinas Kesehatan Kota Padang.(2013). Babi Pendahulun. Retrieved from: https: //arsipskpd.batam.go.id/batamkota/skpd.batamkota.go.id/kesehat an/files/2015/05/Profile-dinkes-2014-pdf-1.pdf

Greenstein. B. \& Wood, D. (2007). At a Glace Sistem Endokrin. Edisi Kedua.Diterjemahkan oleh: dr. Elizabeth Yasmine. Jakarta: Erlangga

Grewen, K.M., Stuebe, A.M. \& Meltzer-Brody, S. (2013). Association Between Maternal Mood and Oxytocin Response to Breastfeeding. Journal of Women's Health, 22(4), pp 352-361 
Holbrook,J., Schetter,C.D.\& Haselton, M.(2012). Breastfeeding and Maternal Mental and Physical Health. Retrieved from: https://cds.psych.ucla.edu/ documents/HahnHolbrookwomenhealthpsychology. pdf

Kementerian Kesehatan RI. (2015). Profil Kesehatan Indonesia Tahun 2014. Jakarta: Pusat Data dan Informasi Kemenkes Republik Indonesia.

Maryunani, A. (2012). Initiation of Early Breastfeeding, Exclusive Asi and Management Lactation . CV Trans Info Media: Jakarta

Noel, G.L., Suh, H.K.\& Frantz, A.G. (2009). Prolactin Release During Nursing and Breast Stimulation in Po -stpartum and Nonpostpartum Subjects.The Journal of Clinical Endocrinology \& Metabolism,38(3), pp 413-423

Pediatrics. (2005).Breastfeeding and the use of human milk. Official Journal of The American Academy of Pediatrics. 115;496. American Academy of Pediatrics.
Riordan, J.(2005). Breastfeeding and Human Lactation. 3rd Edition, Jones and Bartlett Publishers, USA

Riskesdas. (2013). Riset Kesehatan Dasar. Retrieved from: http://www.depkes.go.id/resources/down load/general/Hasil\%20Riskesdas\%202013.pdf

Roesli, U. (2008). Inisiasi Menyusui Dini Plus Asi Ekslusif. Jakarta : Pustaka Bunda.

Sherwood, L. (2011). Fisiologi Manusia Dari Sel ke Sistem Edisi Keenam. Jakarta: EGC.

UNICEF. (2007). Breast Crawl Initiation of Breastfeeding by Breast Crawl. Retrieved from: http://breastcrawl.org

World Health Organization. (2009). Infant and Young Child Feeding: Model Chapter for Text books for Medical Students and Allied Health Professionals. session 2 . The physiological basis of breast feeding. Diunduh melalui. Retrieved from:http://www.ncbi.nlm.nih.gov 